\title{
Modeling of the Mechanical Behavior of Composite at Different Relative Humidities
}

\author{
A. Naceri \\ Mohammed Boudiaf University, M’sila, Algeria
}

УДК 539.4

\section{Моделирование механического поведения композита при различных значениях относительной влажности}

\section{А. Насери}

Университет им. Мохаммеда Будиафа, г. Мсила, Алжир

Для 12-слоистого ламината с матрицей из эпоксидной смольл и стекловолокон исследовань закономерности абсорбции влаги и механического поведения в условиях сдвига. Экспериментальнье исследования абсорбиии влаги образиами из ламината при различньх значениях влажности воздуха (0, 60 и 96\%) при температуре $60^{\circ} \mathrm{C}$ позволили определить два параметра (коэффициент диффузии $D$ и максимальное количество влаги при насыиении $M_{m}$ ), характеризуюиих закон диффузии Фика, которьй предполагает обратилость проиесса. Анализ механического поведения при сдвие, обеспечиваемом одноосным растяжением лалината с волокнами, ориентированныли под углом $45^{\circ} \mathrm{\kappa}$ оси растяжения, при постоянньх скоростях перемещения показал, что при влажности 96\% концентрация влаги в композите играет особенно важную роль. Предложена простая модель, позволяющая описать влияние абсорбцзии влаги на механическое поведение ламината при сдвиге.

Ключевые слова: абсорбция влаги, композит с упрочнением стекловолокнами, стекло, эпоксидная смола, механическое поведение

Introduction. The combination of moisture and temperature has previously been found $[1,2]$ to degrade the mechanical properties of composite materials by enhancing damage growth. Moisture absorption is characterized by the migration of molecules down the concentration gradient, which occurs through diffusion. The properties of the matrix (resin) can also change significantly during exposure to an aquaous environment $[3,4]$. Furthermore, the water can diffuse between the fibers and the matrix, weakening or destroying the bond at the fiber/matrix interface. The amount of moisture absorption during of specific period of time $(t)$ depends on the diffusion coefficients of the individual component in the plastic/composite. For fiber-reinforced plastic composites, the diffusion coefficient depends on the following three factors: volume or weight fraction of fibers, diffusion coefficient of the matrix (base resin) and temperature [5, 6]. The driving force for moisture diffusion is the gradient in the moisture concentration. For homogeneous materials, the moisture diffusion follows the Fick diffusion law. It was observed [7] that moisture absorption in fiber-reinforced plastics correlated very well with the Fick diffusion law. In this study, we have estimated characteristics of moisture absorption 
behavior by assuming one-dimensional diffusion. The main assumption involved is that moisture diffusion can be described by the Fick diffusion law. Additionally, diffusivity is assumed to depend only on temperature and to be independent of moisture concentration or the stress levels inside the material.

If the initial temperature and moisture content in the specimen are uniform, and if the geometry allows for the assumption of a one-dimensional diffusion through the tickness, then the percent moisture content (by weight). The relative moisture absorption can be described by the following equation [8]:

$$
\begin{gathered}
G=\frac{m-m_{j}}{m_{m}-m_{j}}, \\
G=1-\frac{8}{\pi^{2}} \sum_{j=1}^{\infty} \frac{1}{(2 j+1)^{2}} \exp \left[-\frac{(2 j+1)^{2} \pi^{2} D_{x} t}{h^{2}}\right],
\end{gathered}
$$

where $m_{i}$ is the initial weight of the moisture in the material, $m_{m}$ is the weight of moisture in the material when the material is fully saturated, in equilibrium with its environment, and $D_{x}$ is the mass diffusivity in the composite. This is an effective diffusivity since all the heterogeneities of the composites have been neglected. Here $h$ is thickness of specimen and $t$ is the time. The moisture content is measured by finding the weight gain of the material.

The percent moisture content of the composite as a function of time was measured according to mass gain, using the following formula [9]:

$$
M(\%)=\frac{W_{w e t}-W_{d r y}}{W_{d r y}} \cdot 100
$$

where the wet and dry weights are denoted by $W_{\text {wet }}$ and $W_{d r y}$, respectively. By solving the diffusion equation for weight of the moisture, and rearranging in terms of percent moisture content, the following relation is obtained

$$
\begin{gathered}
D=\pi\left[\frac{h}{4 M_{m l}}\right]^{2}(\text { slope })^{2}, \\
\text { slope }=\frac{M_{b}-M_{a}}{\sqrt{t_{b}}-\sqrt{t_{a}}}=\frac{4 M_{n t}}{h \sqrt{\pi}} \sqrt{D},
\end{gathered}
$$

where $M_{m}$ is the equilibrium moisture content of the specimen. Using the weight gain data of the material with respect to time, a graph of percent moisture content of the material vs square root of time is plotted.

We perform the analysis of mechanical response of a laminate constituted of 12 layers of glass fiber fabric/epoxy resin saturated at different relative humidities 0,60 , and $96 \% \mathrm{RH}$ at $60^{\circ} \mathrm{C}$. 
The first part of this study consist to determine the two parameters characteristic of the Fick diffusion law (the diffusion coefficient $D$ and the maximum quantity of water saturation $M_{m}$ ) which admits the reversibility of the phenomenon and the second part consist in testing the specimens oriented at $45^{\circ}$ in uniaxial tension until the failure at constant imposed displacement rates.

Experimental. Material. The material used was a laminate constituted of 12 layers of glass fiber/epoxy resin in one sequence $[ \pm 45]_{3 s}$. The physical properties of woven fabric composite (glass fiber fabric/epoxy resin) studied are presented in Table 1 . The test is carried out on specimen with a length $200 \mathrm{~mm}$, thickness $3.2 \mathrm{~mm}$ and width of $30 \mathrm{~mm}$.

$\mathrm{T}$ a b 1 e 1

Physical Properties of Woven Fabric Composite

\begin{tabular}{|c|c|c|c|}
\hline Composite & Thickness $(\mathrm{mm})$ & Density $\left(\mathrm{g} / \mathrm{cm}^{3}\right)$ & Fiber volume fraction (in \%) \\
\hline Fabric composite & 3.2 & 1.94 & 55 \\
\hline
\end{tabular}

Environmental Conditioning. After total drying in a vacuum oven, the specimens were exposed to various moist environments in an environmental conditioning chamber. A periodic weighing allowed to ensure that a physical equilibrium had been reached before testing. The experimental analysis of the kinetics of moisture absorption of the specimens conditioned in wet medium at different relative humidities, 0,60 , and $96 \% \mathrm{RH}$ at $60^{\circ} \mathrm{C}$ was carried out by a measurement of resumption of weight (gravimetric method) according to the duration of conditioning with an aim of determining the two parameters characteristic of the Fick diffusion law (the diffusion coefficient $D$ and the maximum quantity of water of saturation $M_{m}$ which admits the reversibility of the phenomenon. The equilibrium moisture level of saturation of material was reached about six months. The aim is to study the environmental behavior (moisture absorption) of glass fiber fabric/resin epoxy. This method is used to calculate the diffusivity $D$ and the maximum moisture content $M_{m}$ of the woven fabric composite.

Mechanical Test. The $[ \pm 45]_{3 s}$ laminate was tested in off-axis configuration. Each specimen $(200 \times 30 \times 3.2 \mathrm{~mm})$ was equipped with aluminum end-tabs and three-directional rosettes. All the specimens were carefully conditioned: after prior total drying, the specimens were exposed to various moist environments. A periodic weighing allowed to ensure that a physical equilibrium had been reached before testing. The test itself was performed in a temperature- and moisturecontrolled environmental chamber. Both conditioning and testing were carried on at $60^{\circ} \mathrm{C}$, value chosen to enhance matrix influence on the material behavior. The test was a tensile loading up to failure at constant imposed displacement rates.

Results and Discussion. Moisture Diffusion. The influence of environmental conditions (absorbed moisture) for the lamina (glass fiber fabric/epoxy resin) is discussed. Table 2 shows the experimental results of moisture absorption of composite (fabric glass/epoxy resin).

The weight gain depends mainly on three parameters: time $(t)$, equilibrium moisture content $\left(M_{m}\right)$, and diffusion coefficient $(D)$. The values (characteristic parameters) of the kinetics of moisture absorption $\left(M_{m}\right.$ and $D$ ) obtained by the 
experimental moisture conditioning method confirms clearly the principal remarks observed: the diffusion coefficient $D$ depends not only on the temperature but also of the relative humidity and the equilibrium moisture content $M_{m}$ depends strongly on the relative humidity.

T a b 1 e 2

Experimental Results of Moisture Absorption of Composite (Fabric Glass/Epoxy Resin)

\begin{tabular}{|c|c|c|}
\hline Humidity RH $(\%)$ & 60 & 96 \\
\hline$D\left(\mathrm{~cm}^{2} / \mathrm{s} \cdot 10^{-8}\right)$ & 1.20 & 0.21 \\
\hline$M_{m}(\%)$ & 0.18 & 1.10 \\
\hline
\end{tabular}

Mechanical Response. The analysis of the mechanical and acoustic behavior in shear of the specimens (Table 3), conditioned at different relative humidities 0 , 60 , and $96 \% \mathrm{RH}$ at $60^{\circ} \mathrm{C}$, tested in uniaxial tension at constant imposed displacement rates, has allowed to show that the influence of the moisture concentration for the specimens oriented at $45^{\circ}$ is very important at $96 \% \mathrm{RH}$. This effect is particularly observed for the specimens oriented at $45^{\circ}$ through the evolutions of the tangent shear modulus $\left(G_{06}\right)$, the ultimate shear stress $\left(\sigma_{6 u}\right)$, and the ultimate shear strain $\left(\gamma_{6 u}\right)$ with the variation of the quantity of water absorbed by the composite.

$\mathrm{T}$ a b 1 e 3

Mechanical Responses at Different Relative Humidities

\begin{tabular}{|c|c|c|c|}
\hline $\begin{array}{c}\text { RH }(\%) \\
\text { at } 60^{\circ} \mathrm{C}\end{array}$ & $\begin{array}{c}0 \\
(\text { dry })\end{array}$ & $\begin{array}{c}60 \\
\text { (wet) }\end{array}$ & $\begin{array}{c}96 \\
\text { (wet) }\end{array}$ \\
\hline$M_{m}(\%)$ & 0 & 0.17 & 1.10 \\
\hline$G_{06}(\mathrm{GPa})$ & 6.08 & 5.55 & 3.49 \\
\hline$\sigma_{6 u}(\mathrm{MPa})$ & 145 & 128 & 100 \\
\hline$\gamma_{6 u}(\%)$ & 15.83 & 11.00 & 9.80 \\
\hline
\end{tabular}

From the preceding study it follows that it is reasonable to model the lamina (glass fiber fabric/epoxy resin) behavior by a definite shear modulus-shear strain relationship. We propose here the following exponential law:

$$
\frac{G_{6}-G_{1}}{G_{06}-G_{1}}=\exp \left(-\frac{\gamma_{6}}{\gamma_{06}}\right) \text {. }
$$

The asymptotic value $G_{1}$ of expression (6) is not easy to determine from experimental plots, due to its nature. However, it can be assumed to fall within the range $0.1-0.2 \mathrm{GPa}$ and will be determined with more sensitivity by fitting the computed laminate response to the experimental curves, as the sequel will show. Nevertheless, choosing any value in the range $0.1-0.2 \mathrm{GPa}$ has no great influence on the values of $G_{06}$ and $\gamma_{06}$ obtained in plotting $\ln \left(G_{6}-G_{1}\right)$ versus $\gamma_{6}$. We admit that the agreement is acceptable in the first approximation between the 
proposed model and the experimental data. Table 4 summarizes of $G_{06}, G_{1}$, and $\gamma_{06}$ derived from tests on $[ \pm 45]_{3 s}$ for various humidities. From the data in Table 3, two main features can be pointed out:

(i) the different methods used to determine the shear modulus correspond to different mechanical states of the lamina, and the evolution of the shear modulus governed by the value of $\gamma_{06}$ depends on that mechanical state;

(ii) humidity both reduces the initial shear modulus, especially beyond $60 \%$ (the decrease from dry to $96 \% \mathrm{RH}$ specimens is $43 \%$, and activates its decrease, with $\gamma_{06}$ varying from $31 \%$ for $[ \pm 45]_{3 s}$ ).

$\mathrm{T}$ a b 1 e 4

Results of the Principal Parameters of the Model Proposed

\begin{tabular}{|c|c|c|c|}
\hline Humidity RH (\%) & $G_{1}(\mathrm{GPa})$ & $G_{06}(\mathrm{GPa})$ & $\gamma_{06}(\%)$ \\
\hline 0 & 0.080 & 6.08 & 0.62 \\
\hline 60 & 0.180 & 5.55 & 0.55 \\
\hline 96 & 0.200 & 3.49 & 0.43 \\
\hline
\end{tabular}

Thus, environmental conditions prove to have a prominent influence on the mechanical behavior of epoxy-based composites. The comparison between experimental and computed stress-strain responses of $[ \pm 45]_{3 s}$ are shown in Fig. 1, where there is a good fit for all moisture contents.

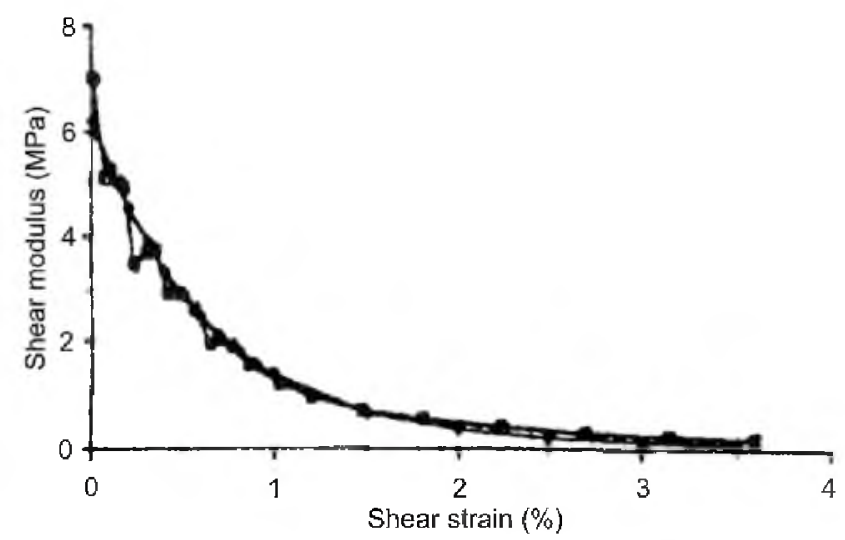

Fig. 1. Comparison between experimental and computed responses for $[ \pm 45]_{3 s}$ specimen $[(\square)$ experimental, ( ) modeling].

A good agreement between the plotted curves (modeled and experimental) of the model proposed of behavior in shear justifies a good control of the nonlinearity of the mechanical response in shear of material tested (Fig. 1).

The straight line of the curve (Fig. 2) representing the initial tangent shear modulus versus characteristic strain by taking account of the maximum quantity of water retained at the saturation $\left(M_{m}\right)$ for the conditioned specimens with various relative humidities $\left(0,60\right.$, and $96 \% \mathrm{RH}$ at $\left.60^{\circ} \mathrm{C}\right)$, made it possible to propose a simple model of the straight line obtained allowing for the sensitivity of behavior in shear to the moisture and at the stressed state. 


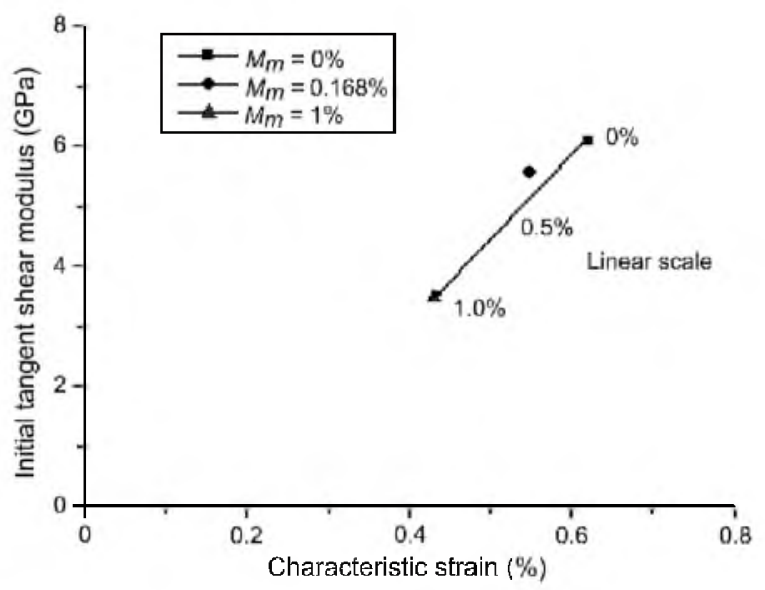

Fig. 2. Initial tangent shear modulus $G_{06}$ vs characteristic strain $\gamma_{06}$

The proposed equation for the straight line is as follows:

$$
G_{06}=a \gamma_{06}-b,
$$

where $a$ is the slope of the straight line of the function in linear scale, and $b$ is the initial value (intersection of the straight line with the $y$-axis for $\gamma_{06}=0$ ) of the modulus of rigidity of the function in linear scale.

The graduation of the straight line (Fig. 2) in linear scale of $M_{m}$ which corresponds to a well-defined scale, allows us to specify the value of the initial tangent initial shear modulus and the characteristic strain for each quantity of water absorbed.

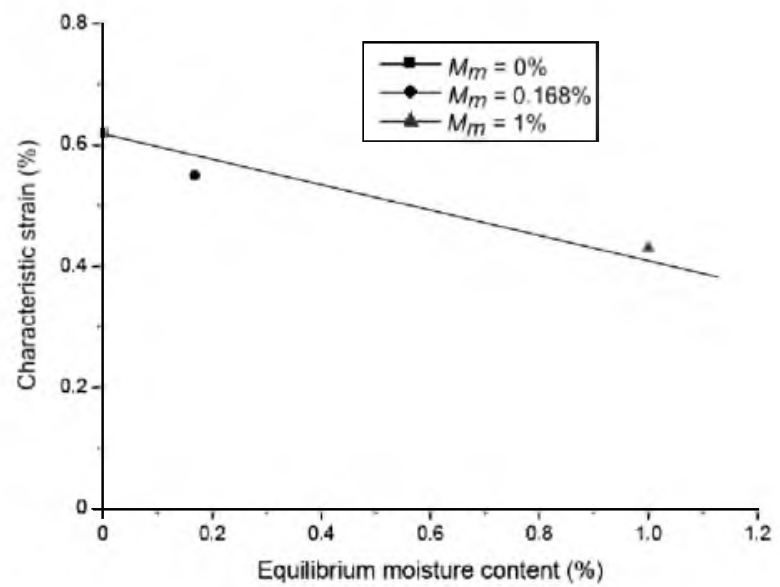

Fig. 3. Characteristic strain $\gamma_{06}$ vs maximum quantity of water retained at the saturation $M_{m}$.

The plotted curve (Fig. 3) representing the characteristic strain versus the maximum quantity of water retained at the saturation by fabric composite makes it possible to determine the coefficients $a^{\prime}$ and $b^{\prime}$ according to the equation obtained 


$$
\gamma_{06}=b^{\prime}-a^{\prime} M_{m}
$$

where $M_{m}$ is the maximum quantity of water retained at the saturation (\%), $a^{\prime}$ is the slope of the straight line of the function in linear scale, and $b^{\prime}$ is the initial value (intersection of the straight line with the $y$-axis for $M_{m}=0$ ) of the characteristic strain of the function in linear scale.

This model describes the influence of water absorption on the mechanical behavior in shear.

Conclusions. Experimental results for laminate constituted of 12 layers of glass fiber/epoxy resin having fiber orientation at $[ \pm 45]_{3 s}$ exposed to humid environment (absorbed moisture) and mechanical tests have been presented. Moisture absorption takes place through of a diffusion process, in which water molecules are transported from areas with moisture concentration. The amount of moisture absorption during the hygrothermal conditioning depends on the diffusion coefficients of the component in the plastic/composite. For fiber reinforced plastic composites, the diffusion coefficient depends on the following three factors: diffusion coefficient of the matrix (resin), temperature and volume or weight fraction of fibers. The moisture diffusion process is highly dependent on the temperature and relative humidity. The analysis of the mechanical behavior in shear of the specimens, conditioned at different relative humidities 0,60 , and $96 \%$ $\mathrm{RH}$ at $60^{\circ} \mathrm{C}$, tested in uniaxial tension at constant imposed displacement rates has permitted allowed to show that the influence of the moisture concentration for the specimens oriented at $45^{\circ}$ is very important at $96 \% \mathrm{RH}$. This effect is particulary observed for the specimens oriented at $45^{\circ}$ through the evolutions of the shear modulus and the shear stress with the variation of the quantity of water absorbed by the composite. The proposed simple model permits to specify the influence of water absorption on the mechanical behavior in shear.

\section{Рез юм е}

Для дванадцятишаруватого ламіната 3 матрицею 3 епоксидної смоли і скловолокон досліджено закономірності абсорбції вологи і механічної поведінки в умовах зсуву. Експериментальні дослідження абсорбції вологи зразками 3 ламіната за різних значень вологості повітря (0, 60 і 96\%) при температурі $60^{\circ} \mathrm{C}$ дозволили визначити два параметри (коефіцієнт дифузії $D$ і максимальну кількість вологи при насиченні $M_{m}$ ), що характеризують закон дифузії Фіка, який припускає зворотність процесу. Аналіз механічної поведінки при зсуві, що забезпечується одновісним розтягом ламіната 3 волокнами, орієнтованими під кутом $45^{\circ}$ до осі розтягу, при постійних швидкостях переміщення показав, що при вологості 96\% концентрація вологи в композиті грає особливо важливу роль. Запропоновано просту модель, яка дозволяє описати вплив абсорбції вологи на механічну поведінку ламіната при зсуві.

1. P. R. Ciriscioli, W. I. Lee, D. G. Peterson, et al., J. Compos. Mater., 21, 225 (1987).

2. A. Chateauminois, B. Chabert, J. P. Soulier, and L. Vincent, Composites, 7, 547 (1998). 
3. I. Verpoest and G. S. Springer, J. Reinf. Plas. Compos., 17, 2 (1988).

4. Y. C. Zhang and X. Wang, J. Reinf. Plas. Compos., 25, 71 (2006).

5. G. Camino, M. P. Luda, A. Y. Polishchuk, et al., Compos. Sci. Technol., 57, 1469 (1997).

6. J. Lundgren and P. Gudmundson, Compos. Sci. Technol., 59, 1983 (1999).

7. E. C. Botelho, L. C. Pardini, and M. C. Rezende, J. Mater. Sci., 41, 7111 (2006).

8. F. Jacquemin and A. Vautrin, Compos. Sci. Technol., 62, 567 (2002).

9. Y. Weitsman, Fatigue Compos. Mater., 385 (1990). 